RESIDENT

\& FELLOW

SECTION

Section Editor

Mitchell S.V. Elkind, MD, MS

Address correspondence and reprint requests to Radhika Dhamija, Department of Neurology, Division of Child and Adolescent Neurology, Mayo Building, 16th floor, Mayo Clinic, 200 First Street SW, Rochester, MN 55905 dhamija.radhika@mayo.edu

\section{Teaching NeuroImages: \\ CT scan of congenital \\ cytomegalovirus infection}

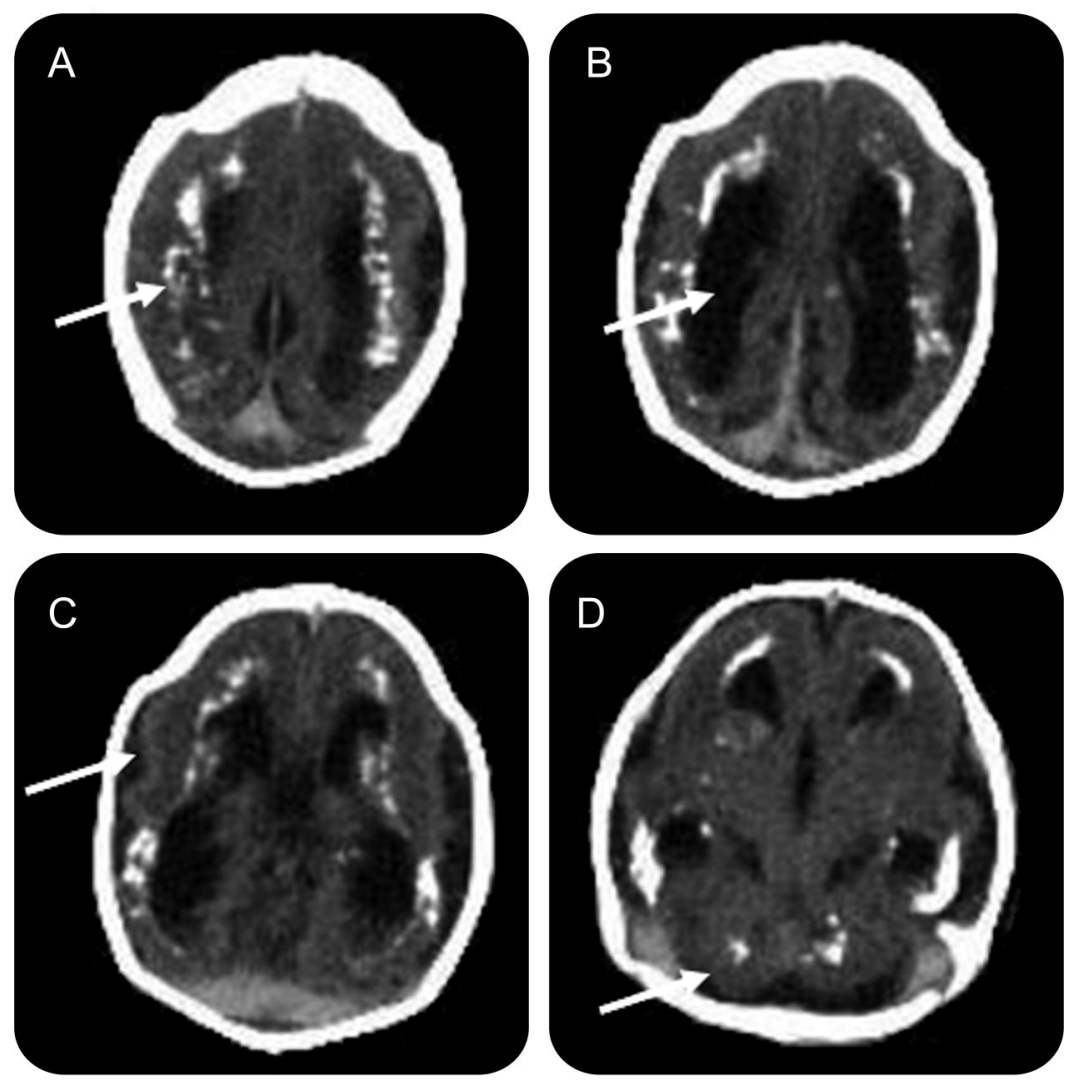

Axial CT scan of the brain at day 1 of life shows (A) extensive periventricular calcifications, (B) ventriculomegaly, (C) reduced cortical sulcation, and (D) cerebellar hypoplasia.

A 20-week fetal ultrasound demonstrated a head circumference less than the 2.5 th percentile. Amniocentesis confirmed cytomegalovirus by PCR. A microcephalic baby was born at term. Head CT was done at day 1 of life (figure). Brain MRI, though more sensitive for malformations of cortical development, was not performed due to requirement for sedation.

Cytomegalovirus is the most common congenital viral infection in the United States, affecting $0.5 \%$ to $2 \%$ of live births with about $90 \%$ of cases being asymptomatic. Factors associated with poor neurode- velopmental outcome include microcephaly, chorioretinitis, and neuroradiologic abnormalities. ${ }^{1,2}$

\section{REFERENCES}

1. Boppana SB, Fowler KB, Vaid Y, et al. Neuroradiographic findings in the newborn period and long-term outcome in children with symptomatic congenital cytomegalovirus infection. Pediatrics 1997;99:409-414.

2. Noyola DE, Demmler GJ, Nelson CT, et al. Congenital CMV Longitudinal Study Group. Early predictors of neurodevelopmental outcome in symptomatic congenital cytomegalovirus infection. J Pediatr 2001;138:325-331. 


\title{
Neurology
}

\author{
Teaching NeuroImages: CT scan of congenital cytomegalovirus infection \\ R. Dhamija and G. Keating \\ Neurology 2011;76; e13 \\ DOI 10.1212/WNL.0b013e3182074a7d
}

\section{This information is current as of January 17, 2011}

Updated Information \&

Services

References

Subspecialty Collections

Permissions \& Licensing

Reprints including high resolution figures, can be found at: http://n.neurology.org/content/76/3/e13.full

This article cites 2 articles, 0 of which you can access for free at: http://n.neurology.org/content/76/3/e13.full\#ref-list-1

This article, along with others on similar topics, appears in the following collection(s):

All Pediatric

http://n.neurology.org/cgi/collection/all_pediatric

CT

http://n.neurology.org/cgi/collection/ct

Viral infections

http://n.neurology.org/cgi/collection/viral_infections

Information about reproducing this article in parts (figures,tables) or in its entirety can be found online at:

http://www.neurology.org/about/about_the_journal\#permissions

Information about ordering reprints can be found online:

http://n.neurology.org/subscribers/advertise

Neurology ${ }^{\circledR}$ is the official journal of the American Academy of Neurology. Published continuously since 1951, it is now a weekly with 48 issues per year. Copyright Copyright (? 2011 by AAN Enterprises, Inc.. All rights reserved. Print ISSN: 0028-3878. Online ISSN: 1526-632X.

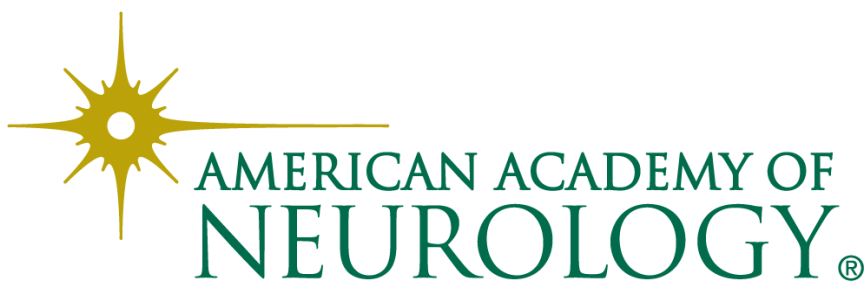

